\title{
CHANGING THE BODY COMPOSITION PARAMETERS IN WOMEN OF BOTH PERIODS OF THE MATURE AGE ENGAGED IN POWER FITNESS
}

\author{
Petro Mohyla Black Sea National University, Mykolaiv, Ukraine
}

chernozub@gmail.com

Results of the research on determining impact of experimental models of training in strength fitness on body composition parameters among women aged 21 to 55 years are represented in the article. To perform the task and achieve the aim of the study we have formed two research groups: 1) women aged 21 to 35 years; 2) women aged 36 to 55 years. As a result we have discovered that studied parameters of bioelectrical impedance analysis (BIA) during the usage of proposed models of training for three months show the same dynamics in both groups, but with rather different progression. The body fat index of women aged 21 to 35 years reduced by $7.9 \%(p<0.05)$ during the experiment compared with the initial data. This indicator in the group of people aged 36 to 55 years also shown a decline, but only by 3.8\% $(p<0,05)$ over the same period of time. This dynamics was also fixed while examining other indicators of the body composition throughout the experiment period. Thus, we can assume that women of the first group consume more energy in these conditions of intense muscular activity in comparison with those of the other group. At the same time, the analysis of the results of the experiment shown that the level of primary adaptation to loads of strength character was higher in the members of the second group regardless of their age and significantly higher initial parameters of body composition.

Keywords: strength fitness, adaptive changes, women of mature age, load, body composition, bioelectrical impedance analysis.

Research relation to the plans, programs and department themes. The article is a fragment of the planned scientific work "Development and implementation of innovative technologies and correction of the functional state of a man with physical activity in sports and rehabilitation", state registration number 0117 U007145.

Introduction. The problem of finding new approaches to the human body improvement using various forms of motor activity has been one of the priority directions of scientific research in physical culture and sports, human physiology, sports medicine in recent years $[1,5,6,13]$.

At the same time, there arises an acute problem of determining the adequacy of physical training systems, training loads parameters and a person's gender characteristics, age, functional capabilities of the organism by virtue of considerable popularization of fitness and countless numbers of its variations in the world [2, 12].

Most studies presented in the scientific literature $[6,9,12,15]$ are mainly aimed at determining the impact of fitness on the morphometric indices of the examined contingent (anthropometric data), the development of strength capabilities of the organism, the dynamics of heart rate in response to acute physical activity and duration of its retrieval to a level at the state of rest. However, the problem concerning introduction of integrated control (on the basis of biochemical and physiological criteria) over the adequacy of the training load and functional capabilities of the human body during high intensity loads is not fully studied. This does not permit to determine the effectiveness of adaptive changes in the organism in the process of intense motor activity.

Thus, the Main Purpose of our research is to determine the peculiarities of changes in body composition parameters among women of different age in the process of long-term fitness exercises using an experimental model of training based on exercises with body weight.

Material and Research Methods. During the research we examined 51 practically healthy mature women (aged 21 to 55 years) who had not previously been engaged in fitness and other sports. Taking into account the purpose and objectives of the study two experimental groups were formed: women aged 21 to 35 years (the first group) and women aged 36 to 55 years (the second one).

An experimental model of muscle activity consisted in using a load of strength character during three months of training. Women had three lessons 
per week. Exercises were performed with own body weight to full muscle fatigue of the working muscle group in each set. The rest interval between the sets varied from 30 to 50 seconds. Physical exercises were carried out according to the technology we have determined (amplitude, duration of concentric and eccentric phases of motion), which allowed to involve only those muscle groups that took an active part in exercises of the same type using training apparatuses. This method of load optimization allowed us to develop experimental training programs without the use of specialized complex training apparatuses. It positively influenced the number of participants who could simultaneously perform physical exercise of the same type. These circumstances made it possible to substantially simplify the mechanism of technical control over the training process.

All participants who took part in the research had passed medical examination and biochemical laboratory control (16 indicators). According to the results, women had no medical contraindications for participation in the research.

The dynamics of the studied parameters of bioelectrical impedance analysis (BIA) (human body composition) was estimated at the beginning of the study and within three months of systematic fitness exercises at one month intervals. To evaluate the above mentioned indicators we used a BIA analyzer: the diagnostic computerized hardware and software complex KM-AP-01 "Diamant-AST" (body composition analyzer) (VJUSK. 941118.001 PE) [3].

Statistical processing of the results was carried out using the statistical software IBM * SPSS * Statistics 20. To characterize the studied parameters, the arithmetic mean of the sample population (M) was calculated. Indicators of the variation of the results obtained were the standard deviation $(\sigma)$ and $\mathrm{m}$ - the representation error (general average). The test of normality was carried out using the Kolmogorov-

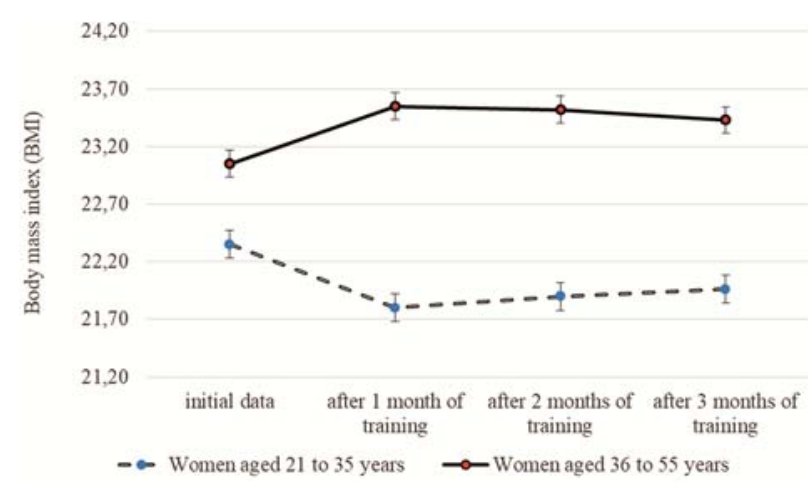

Fig. 1. Change in the body mass index (BMI, units of measurement) of women of different ages in the process of 3-month strength fitness training, $n=51$
Smirnov test. If the normal distribution of data was confirmed, then the reliability of the differences was estimated using the parametric Student's t-test for connected and noncontiguous samples at the level of significance $p<0,05-0,001$ [10].

Results of the Research and their Discussion. During the experimental research on determining the peculiarities of changes in the indices of bioelectrical impedance analysis in the process of systematic going in for strength fitness and using our models of training by the examined contingent, we have obtained the results that demonstrate a rather diverse intergroup tendency of controlled indicators (Fig. 1-4).

Fig. 1 shows the results of the dynamics of the body mass index of women from both groups in the process of 3-month strength fitness training. It has been established that at the beginning of the experiment we did not observe significant differences in the studied indicators among the participants from both groups, which would allow more accurately assess the effectiveness of the proposed training program. Thus, we have found out that women from the first group got a decrease in the index of body mass by $1.8 \%$ during all stages of the study. At the same time, among representatives of the other age group this indicator increased by $1.6 \%$ over the same period of time.

Thus, the obtained results indicate that the use of the given model of fitness training more positively affects the level of fitness of women from the second group (aged 36 to 55 years) and demonstrate their adaptive potential.

Evaluating the changes in fat mass of the body of the participants we have detected a significant discrepancy in the controlled parameters at the beginning of the experiment. However, the findings did not correspond to the generally accepted parameters of bioelectrical impedance analysis according to the age characteristics of the contingent [8]. Thus, at the beginning of the experiment, the fat mass index in

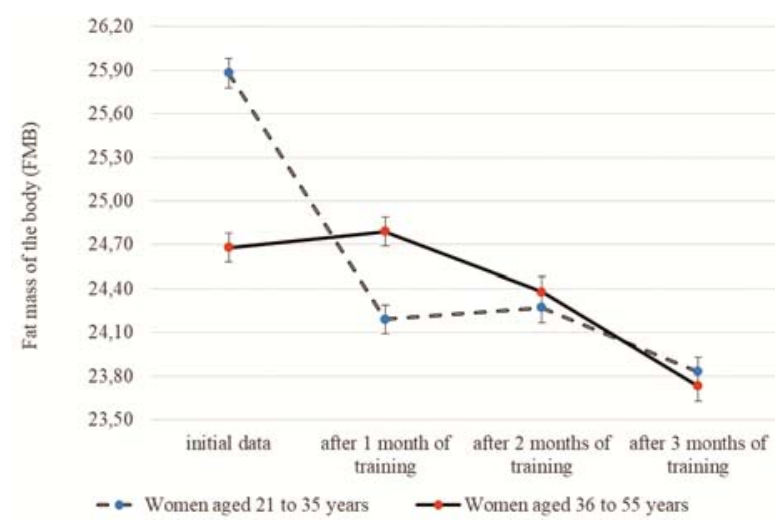

Fig. 2. Change in the fat mass of the body (FMB, \%) of women of different ages in the process of 3 -month strength fitness training, $n=51$ 


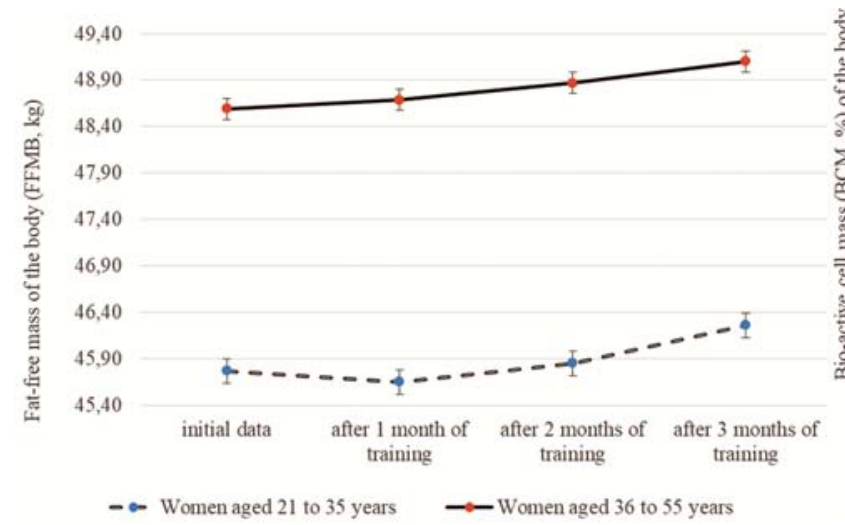

Fig. 3. Change in fat-free mass of the body (FFMB, $\mathrm{kg})$ of women of different ages in the process of 3-month strength fitness training, $n=51$

women of the second group was higher by $4.6 \%$ $(p<0.05)$ compared with the other experimental group.

At the same time, the analysis of the results of the examination conducted over a period of three months suggests that the body fat index of women aged 21 to 35 years and who went in for fitness systematically was reduced by $7.9 \%(p<0.05)$ compared with the initial data. This indicator in the group of people aged 36 to 55 years also shown a decline, but only by $4.3 \%$ $(p<0,05)$ over the same period of time.

This fact indicates that the members of the second age group have higher level of the organism adaptation to the given loads, which are typical for strength fitness, compared to the capabilities of the first group representatives.

The results of studying the peculiarities of changing the parameters of the fat-free mass of the body (part of the body weight, which includes everything that does not contain fat: muscles, all internal organs, bones, nerve cells, all liquids that are in the body [3, 8]) are graphically depicted in Fig. 3.

The results show that even the initial data obtained at the beginning of the experiment indicate that the fat-free mass index of women in the second group was by $6.2 \%(p<0.05)$ higher than those fixed in representatives of the other research group. This indicates again that the fitness level of women aged 36 to 55 years is significantly higher compared with the group of women of a younger age (from 21 to 35 years old).

At the same time, studying the dynamics of the parameters of fat-free mass of the body we have discovered that the controlled indicators show a slight increase regardless of the age of the examined contingent.

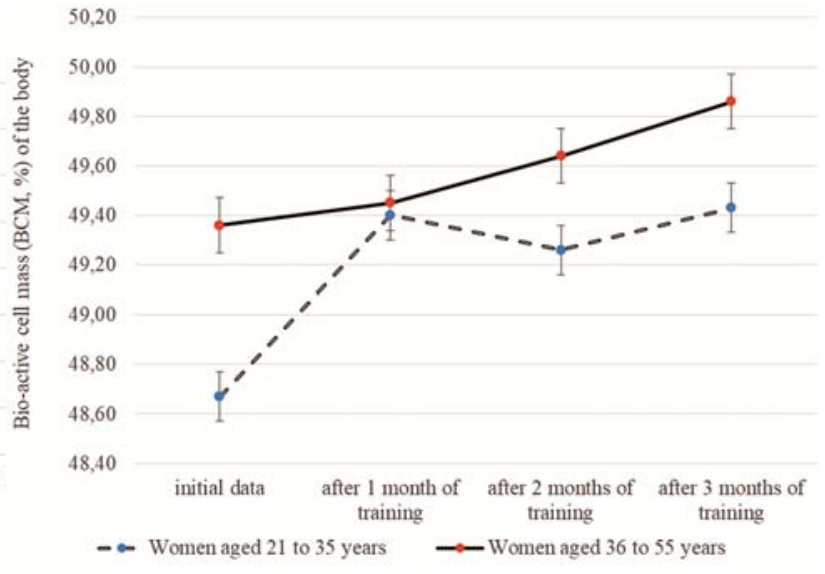

Fig. 4. Change in bio-active cell mass (BCM, \%) of women of different ages in the process of 3-month strength fitness training, $n=51$

Fig. 4 depicts quantitative indicators of bio-active cell mass (BCM, \%) of the body established in representatives of these groups during the three-month control. According to the results obtained, at the beginning of the research (initial data) the indicators shown almost identical parameters among women from both groups.

We have revealed that $\mathrm{BCM}$ of women from the second group increased, but with a minimum dynamics of from 0,1 to $0.5 \%$ after three months of systematic doing fitness and using our model of training. At the same time, we have discovered that the investigated indicator had a tendency both to increase and to decrease among the representatives of the other group. Although it is not reliable.

Thus, during the experimental research we have ascertained that the use of exercises with body weight, the technique of which completely repeats the biomechanics of using specialized training apparatuses, the effectiveness of which is proved by a large number of studies [6], has a positive effect on the dynamics of BIA indicators of women from both groups despite the fact that the primary level of fitness is higher in the group of women aged 36 to 55 years.

\section{Conclusions}

1. We have found that the initial fitness level, taking into account the initial data of active body weight index and parameters of fat-free mass of the body, is significantly higher in women of the second group (36-55 years old) compared with representatives of the other group.

2. Continued use of the experimental model of strength fitness training, based on the method of interval use of exercises with body weight which completely repeat the biomechanics of using specialized training apparatuses, has a positive effect on body composition parameters of the human 
body, as well as the well-known techniques. However, these well-known techniques are more technically complicated and less suitable for general use in order to make people feel healthy.

3. Our model of training consisted of using experimental physical exercises and techniques inherent in strength fitness increases the effectiveness in the group of women aged 21 to 35 years compared with the contingent of the other group.
Prospects for Further Research. Nowadays we need more informative comprehensive diagnostic methods for determining adaptive changes in the organism of people of all ages and sex in conditions of intense muscular activity. Complex biochemical methods for diagnostics of adaptive changes in the will allow to clearly ascertain the efficiency of any model of muscle activity. Additional comprehensive research is necessary to explore this problem more thoroughly.

\section{References}

1. Chernozub AA. Features of adaptive reactions in humans under power fitness. Physiological journal. 2015; 61(5): 99107. https://doi.org/10.15407/fz61.05.099

2. Chernozub AA. The security and critical levels of physical activity for trained and untrained persons in muscle performance power orientation. Physiological journal. 2016; 62(2): 110-6. https://doi.org/10.15407/fz62.02.110

3. Complex KM-AP-01 "Diamant-AST" (body composition analyzer): the manual. Sankt-Peterburg: Diamant; 2007.18 p. [Russian]

4. Goto K, Ishii N, Kizuka T, Kraemer RR, Honda Y, Takamatsu K. Hormonal and metabolic responses to slow movement resistance exercise with different durations of concentric and eccentric actions. European Journal of Applied Physiology, 2009; 106(5): 731-9. PMID: 19430944. DOI: 10,1007 / s00421-009-1075-9

5. Kraemer RR, Castracane VD. Endocrine alterations from concentric vs. Eccentric muscle actions: a brief review. Metabolism. 2015; 64(2): 190-201. PMID: 25467839. DOI: 10,1016/j.metabol.2014.10.024

6. Kudrya O. Adaptation of the cardiovascular system of athletes to loads of different nature. Tomsk State University Journal. 2012; 3(356): 162-6. [Russian]

7. Martín-Hernández J, Marín PJ, Menéndez H, Ferrero C, Loenneke JP, Herrero AJ. Muscular adaptations after two different volumes of blood flow - restricted training. Scandinavian Journal of Medicine \& Science in Sports. 2013; 23 (2): 114-20. PMID: 23278841. DOI: 10,1111/sms.12036

8. Martirosov EG, Nikolaev DV, Rudnev SG. Technologies and methods for determining body composition. Moscow: Nauka; 2006. 248 p. [Russian]

9. Meerson F, Pshennikova, MG. Adaptation to stress and physical loading. Moscow: Meditsina; 1988. 256 p. [Russian]

10. Nasledov A. IBM SPSS Statistics 20 and AMOS: professional statistical analysis of data. Sankt-Peterburg: Piter; 2013. 416 p. [Russian]

11. Philippe A, Py G, Favier FB, Sanchez AM, Bonnieu A, Busso T, Candau R. Modeling the responses to resistance training in an animal experiment study. Biomed Res Int. 2015; 2015: 914860. PMID: 25695093. PMCID: PMC4324815. DOI: $10.1155 / 2015 / 914860$

12. Platonov VN. The system of training athletes in the Olympic sport. General theory and its practical applications. Kiev: Olimpiyskaya literatura; 2004. 808 p. [Russian]

13. Platonov VN. Urgent and long-term adaptation of athletes during the training. Adaptatsyya sportsmenov $k$ trenyrovochnym nagruzkam. K: Kyevskyy gosudarstvennyy ynstytut fyzycheskoy kultury. 1984: 10-29. [Russian]

14. Plews D, Laursen PB, Stanley J, Kilding AE, Buchheit M. Training adaptation and heart rate variability in elite endurance athletes: opening the door to effective monitoring. Sports Med. 2013; 43(9): 773-81. PMID: 23852425. DOI: 10.1007/s40279-013-0071-8

15. Netreba AI, Popov DV, Bravyi YaR, Misina SS, Vinogradova OL. Physiological effects of low-intensity strength training without relaxation. Human physiology. 2009; 35(4): 479-83. https://doi.org/10.1134/S0362119709040136

16. Seynnes OR, Kamandulis S, Kairaitis R, Helland C, Campbell EL, Brazaitis M, Skurvydas A, Narici MV. Effect of androgenic-anabolic steroids and heavy power training on patellar tendon morphological and mechanical properties. Journal of Applied Physiology, (2013). 115 (1), 84-9. PMID: 23620489. DOI: 10,1152/japplphysiol.01417.2012

\section{УдК 796.412 \\ ЗМІНА ПАРАМЕТРІВ СКЛАДУ ТІЛА У ЖІНОК ОБОХ ПЕРІОДІВ ЗРІЛОГО ВІКУ ПРИ ЗАНЯТТЯХ СИЛОВИМ ФІТНЕСОМ \\ Timoва Г. В.}

Резюме. У роботі представлені результати досліджень щодо визначення особливостей впливу експериментальних моделей тренувальних занять в силовому фітнесу на динаміку показників складу тіла жінок зрілого віку обох періодів. Для вирішення мети та завдань дослідження з обстеженого контингенту було сформовано дві дослідні групи: 1) жінки віком 21-35 років; 2) жінки віком 36-55 років. В результаті проведених досліджень встановлено, що контрольовані показники біоімпедансометрії протягом трьох місяців 
використання запропонованих нами для представників обох дослідних груп моделей тренувальних навантажень демонструють однотипну динаміку, але з достатньо відрізняючою між груповою прогресією. Так виявлено, що у групі жінок віком від 21 до 35 років показник жирової маси тіла зменшується на 7,9\% $(p<0,05)$ за період проведення експерименту порівняно з вихідними даними. В той же час, даний показник складу тіла учасників іншої дослідної групи також демонструє зниження, але всього на $3,8 \%(p<0,05)$ за аналогічний період часу. Відповідну динаміку фіксовано і під час контролю інших показників складу тіла представників всіх дослідних груп протягом всього періоду експерименту. Таким чином, отримані результати дозволяють зробити припущення, що саме у жінок першого періоду зрілого віку більш виражені енергозатрати за даних умов напруженої м'язової діяльності порівняно з учасниками іншої групи. В той же час аналіз результатів експерименту свідчив про те, що рівень первинної адаптації до навантажень силової спрямованості був більш високий саме у осіб другої групи, незважаючи на їх вік та суттєво більші вихідні параметри показників складу тіла.

Ключові слова: силовий фітнес, адаптаційні зміни, жінки зрілого віку, навантаження, склад тіла, біоімпедансометрія.

\section{УДК 796.412 \\ ИЗМЕНЕНИЕ ПАРАМЕТРОВ СОСТАВА ТЕЛА У ЖЕНЩИН \\ ОБОИХ ПЕРИОДОВ ЗРЕЛОГО ВОЗРАСТА ПРИ ЗАНЯТИЯХ СИЛОВЫМ ФИТНЕСОМ \\ Tитова A. B.}

Резюме. В работе представлены результаты исследований по определению особенностей влияния экспериментальных моделей тренировочных занятий в силовом фитнеса на динамику показателей состава тела женщин зрелого возраста обоих периодов. Для решения целей и задач исследования обследованного контингента были сформированы две исследовательские группы: 1) женщины в возрасте 21-35 лет 2) женщины в возрасте 36-55 лет. В результате проведенных исследований установлено, что контролируемые показатели биоимпедансометрии в течение трех месяцев использования предложенных нами для представителей обоих исследуемых групп моделей тренировочных нагрузок демонстрируют однотипную динамику, но достаточно отличительную между групповой прогрессией. Так установлено, что в группе женщин в возрасте 21-35 лет показатель жировой массы тела уменьшается на 7,9\% ( $p<0,05)$ за период проведения эксперимента по сравнению с исходными данными. В то же время, данный показатель состава тела участников другой исследовательской группы, также демонстрирует снижение, но всего на $3,8 \%(p<0,05)$ за аналогичный период времени. Соответствующая динамика наблюдается и при контроле других показателей состава тела представителей всех исследовательских групп в течение всего периода эксперимента. Таким образом, полученные результаты позволяют предположить, что именно у женщин первого периода зрелого возраста более выражены энергозатраты при данных условиях напряженной мышечной деятельности по сравнению с участниками другой группы. В то же время анализ результатов эксперимента свидетельствовал о том, что уровень первичной адаптации к нагрузкам силовой направленности был более высокий именно у лиц второй группы, несмотря на их возраст и существенно большие выходные параметры показателей состава тела.

Ключевые слова: силовой фитнес, адаптационные изменения, женщины зрелого возраста, нагрузки, состав тела, биоимпедансометрия.

The authors of this study confirm that the research and publication of the results were not associated with any conflicts regarding commercial or financial relations, relations with organizations and/or individuals who may have been related to the study, and interrelations of coauthors of the article. 